\title{
Therapeutic Landscapes and Indigenous Culture: Māori Health Models in Aotearoa/ New Zealand
}

\author{
Jacqueline McIntosh, Bruno Marques and Rosemary Mwipiko
}

\begin{abstract}
Research has shown that Indigenous people suffer significant health inequalities in comparison to dominant colonising cultures. Evidence shows that these inequalities can be addressed by gaining a deeper understanding of the social and cultural determinants of health, applying Indigenous views of health and developing better definitions of the term wellbeing. The following chapter draws on research exploring the relationship between Indigenous culture, the landscape and the connection with health and wellbeing. In Aotearoa/New Zealand, consideration of Indigenous Māori is a national imperative, enshrined in the Te Tiriti o Waitangi (Treaty of Waitangi) which establishes it as a bicultural country. Exploring three Māori health models, the chapter examines the factors that play a significant role in shaping Māori people's health. It relates how landscape is a foundational therapeutic aspect of Māori wellbeing using the models to express the forces that impact both positively and negatively on this relationship. The chapter concludes that all three concepts, culture, health and landscape, are interconnected and must be balanced to reduce Māori health inequalities and to provide a more sustainable model for health and wellbeing for all New Zealanders.
\end{abstract}

Keywords: Therapeutic landscapes; health models; Māori; health and wellbeing; indigenous culture; holistic health; health geographies

\section{Introduction}

The intersection of culture, place and health is an area of significant inquiry and can be usefully studied by applying therapeutic landscape theory. Therapeutic landscapes are settings that comprise of the physical, psychological and social

\footnotetext{
Clan and Tribal Perspectives on Social, Economic and Environmental Sustainability, 143-158 
environments associated with treatment and healing (Wendt \& Gone, 2012). Since their introduction nearly 20 years ago, therapeutic landscapes have been predominantly concerned with three areas: physical spaces associated with health; health care delivery locations; and sites that are specific to marginalised populations (Williams, 2009). This is of particular interest in bicultural Aotearoa/New Zealand where colonised Māori carry the greatest burden of health inequalities.

Statistics show that Māori life expectancy is approximately eight years earlier than non-Māori (Ministry of Health, 2015; Robson \& Harris, 2007). In addition to greater health problems, Māori suffer significant social disadvantages, with evidence indicating that even after accounting for factors such as poverty, education and location, disparities between Māori and non-Māori still exist (Marriott \& Sim, 2015). The literature also suggests that inequalities between Māori and non-Māori can be understood by focusing on factors such as social and cultural health determinants, colonisation, intergenerational trauma and holistic notions of wellbeing (Kingsley, Townsend, Henderson-Wilson, \& Bolam, 2013). With a holistic worldview and a critical connection to landscape, the consideration of Māori culture and its impacts on health must be taken into account in any healthcare model.

To bridge the gap in understanding of the Māori view of wellbeing, holistic notions of wellbeing are explored using three Māori health models, which bring a number of different disciplines together to offer an understanding on the significance of contact with the natural world. The models are not about measurement, but they are attempts to move beyond Western models to provide a holistic understanding of Māori views on the connection to nature and to consider the implications of this for wellbeing. While research exploring the individual and collective impact of holistic notions of wellbeing is growing internationally, little is known about the influence of these factors on Māori health and practices (Wirihana \& Smith, 2014), and only a few studies have explored the beliefs systems of Māori and how they shape health (McIntosh, Marques, \& Hatton, 2018; Panelli \& Tipa, 2007).

Following a brief review of the historical context, an examination of the cultural implications of terminology such as health and wellbeing is explored to understand the intricacies of Māori health. The chapter finds that the interconnections between health and wellbeing with the landscape and the subsequent shaping of Māori identity are under-represented in current healthcare models.

\section{Historical Context}

The following is not a comprehensive portrait of New Zealand's history but rather a brief discussion of traditional or pre-European views of Māori followed by an outline of a few major historical events associated with Māori identity. Māori are the Indigenous people (tangata whenua) of Aotearoa/New Zealand and have resided in the country for approximately 1,000 years. As of the last census on major ethnical groups in New Zealand in 2013, they represented around $15 \%$ of 
the population (Zealand, 2013). To understand how the environment helps to shape identity and health, it is crucial to gain an understanding of pre-European Māori social and economic organisation. According to Lo and Houkamau (2012), Māori organised themselves into small communities based on three main social groupings: whānau (family units), hapū (sub-tribes) and iwi (tribes). Family units were central to Māori society and generally comprised three generations of family members of common descent, living together (Walker, 1990). Multiple groups of whānau living together in one area became hapū and multiple hapū merged to form iwi. Each iwi occupied a specific geographical area in New Zealand, called rohe (Lo \& Houkamau, 2012). Difficult living conditions at the time resulted in family units being co-dependent on one another, as multiple families were required to plant, harvest and gather food (Selby, 1999). As a consequence of this communal social and economic structure, Māori identified themselves in relation to their position within their whānau, hapu and iwi, and their position in the landscape. Presently, when Māori are in gatherings or other culturally driven contexts, they introduce themselves by naming their iwi and hapu as well as key landforms, such as mountains, rivers or lakes, important to situate their geographic location in the country (Houkamau, 2006).

Similar to other Indigenous peoples, when Māori were colonised, they lost a significant amount of the land which helped to sustain their traditional lifestyles (Marques, Grabasch, \& McIntosh, 2018b). This loss resulted in many Māori becoming geographically disconnected from their extended family networks and traditional practices (Kokiri, 2000). The challenges of adjusting to new cultural contexts had a significant impact on how they identified themselves and created an underlying sense of dislocation. Over time and other factors, such as economic pressures, access to materials and resources, meant that for Māori to progress economically, they had to move to commercial centres and adjust to Western culture (Marques, McIntosh, Hatton, \& Shanahan, 2019b). This shift has not been without consequences, and it is widely acknowledged that Māori health inequalities have been one outcome of the accumulated effects of colonisation.

\section{Understanding Health and Wellbeing}

Wellbeing is a complex concept, often used in conjunction with terms such as health and quality of life (Kahn \& Juster, 2002). In order to have a deep understanding of the concept of wellbeing, all lived lifespans and their influences on individuals and communities must be considered (Stewart, 2004). McNaught (2011) expands individual subjectivity to accommodate wellbeing as deeply linked with family, community and society as well as with environmental, socioeconomic and political forces. Overall, this means that wellbeing comprises a wide range of dimensions, including physical, psychological, social, mental and spiritual health.

In terms of Māori wellbeing, a large majority of wellbeing indicators produced in Aotearoa/New Zealand indicate negative trends in Māori communities. According to the 2017/18 NZ health survey, Māori adults were about 1.5 times as 
likely as non-Māori adults to report a high or very high probability of having an anxiety or depressive disorder (Ministry of Health, 2019). While these universal indicators can be applied to Māori communities, there are unique characteristics of Māori that require specific measurement; in particular, measures that are in harmony with Māori realities and worldviews. For example, a Māori-specific measure of adequate housing might take into account the level of provision for extended families and visitors, or a measure of educational attainment might include information about the use and knowledge of the Māori language (Durie, 2006). Clearly, there is a significant gap in knowledge with regard to Māori health. Māori continue to experience the worst health outcomes of any population group in Aotearoa/New Zealand (Waitangi Tribunal, 2019). A cultural appropriate health service is deemed essential for the delivery of effective health services for Māori, and a deeper understanding of the foundations of wellbeing and Māori worldviews can help to reduce rates of ill-health within the Māori community.

While currently $88 \%$ of Māori live in urban centres away from their cultural connections, over the last three decades there has been a Māori Renaissance grounded on the revival of language and land claims based in Te Tiriti O Waitangi (Treaty of Waitangi) and supported by the Tribunal of Waitangi. This has meant a shift from a homogenous society to one that embraces a culturally diverse population (Thorns, Fairbairn-Dunlop, \& Du Plessis, 2010), and for Māori it has meant embracing their unique identity by acknowledging their lineage and learning about Māori history, culture and language.

Focusing on Māori definitions of health and examining the role of landscape in shaping health outcomes is a useful starting point. First, Māori conceptions of health can be better understood through a discussion of three Māori health models. Second, the significance of the land as the basis of Māori identity must be considered. Finally, connecting the health models with the landscape emphasises the importance of the interconnectedness of Māori health perspectives.

\section{Examining the Interconnections of Health and Place}

To fully understand the link between land and health, it is useful to explore Māori conceptions of health and wellbeing. The three Māori health models, Te Whare Tapa Wha (the four cornerstones), Te Pae Māhutonga (Southern Cross constellation) and Te Wheke (the octopus), examine the factors that play a role in shaping Māori people's health. Exploring the foundational knowledge from the past is beneficial to understanding the ways that these models are used to deliver healthcare in the current environment and some of the successes from adopting these health values. Each of the models below not only emphasises the importance of the interconnectedness of Māori health perspectives; the associations between the physical, the spiritual, the environmental, the individual and the family, but they also present a way which can inform the construction of therapeutic landscapes that reflect culture and identity. 


\section{Te Whare Tapa Whā: The Four Cornerstones}

The first model, Te Whare Tapa Wha a, conveys the importance of balance and encompasses four main elements using the analogy of a house with four walls (Durie, 2004) (Fig. 11.1). Its first element, taha tinana (physical body), refers to the body and is the physical expression of health and wellbeing. The second element, taha wairua (spiritual realm), reflects the spiritual aspects of wellbeing. The third element, taha whannau (family and community), highlights the need and significance of the family and community to one's health and wellbeing; and the last element, taha hinengaro (mental health), describes the importance of the mind. All four elements are interwoven and interact to support a strong and healthy person. Rochford (2004) suggests if one of these key elements is missing or damaged, then the resulting imbalance may lead to negative health outcomes. To achieve balance and good health, individuals must live in harmony with others, their communities and the spiritual realm.

\section{Te Pae Māhutonga: The Southern Cross Constellation}

The second model, Te Pae Māhutonga, is named after the Southern Cross (constellation of stars) and identifies the magnetic South Pole. Developed in

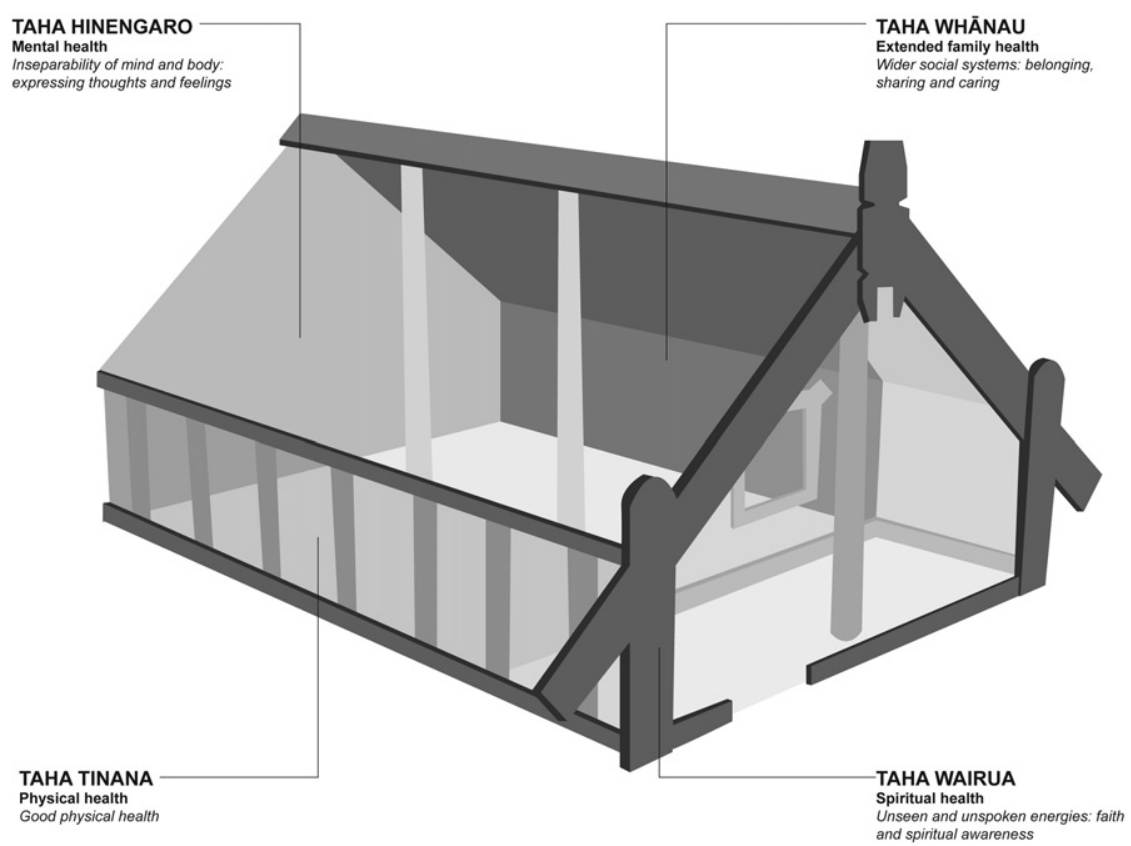

Fig. 11.1. Te Whare Tapa Whā, or the Four Cornerstones, Depicts How the Four Pillars of Health and Wellbeing Come Together.

Source: Author's own 


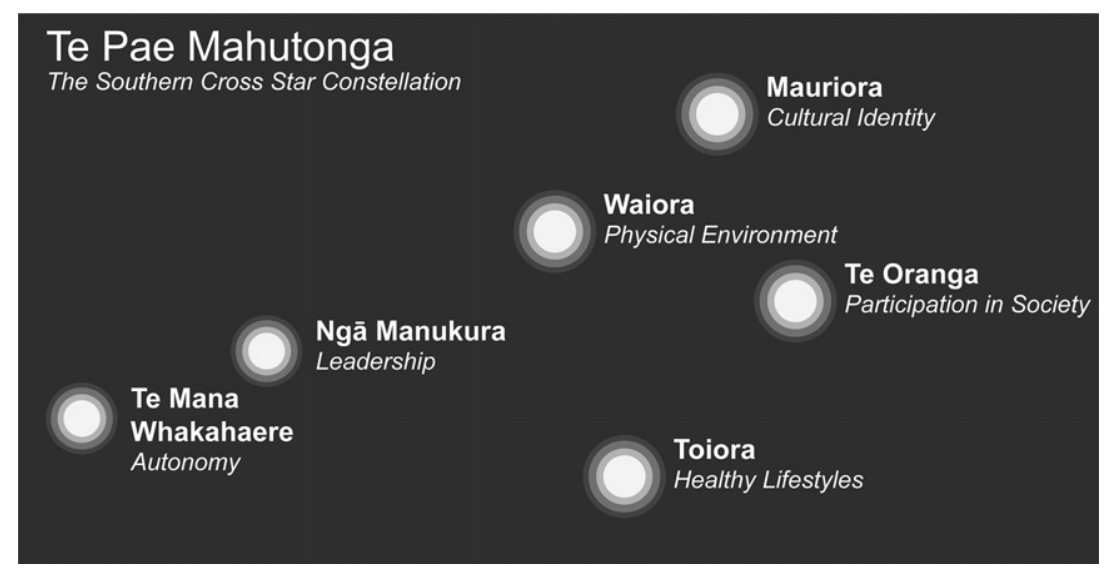

Fig. 11.2. The Southern Cross Constellation, Known as Te Pae Māhutonga, Brings Together Six Overarching Themes for Health and Wellbeing Promotion. Source: Author's own

response to modern Māori cultural deprivation, Durie (2004) advocates greater accessibility through the use of a variety of Māori cultural experiences such as participation in the marae (communal meeting house), waka (ancestral canoe) paddling and other social contexts. These serve to connect to the past through positive models of autonomy and leadership. The model is made up of four central stars arranged in the form of a cross, and there are two stars arranged in a straight line which point towards the cross. These are known as the two pointers (McNeill, 2009). Te Pae Māhutonga (Fig. 11.2) is used as a guide and a symbolic map for bringing together the significant components of health promotion, as they apply to Māori health. The six stars represent specific goals of health promotion: mauriora (cultural identity), waiora (physical environment), toiora (healthy lifestyle), te oranga (participation in society) and the two pointers nga manukura and te mana whakahaere (leadership and autonomy) (Durie, 2004).

\section{Te Wheke: The Octopus}

Te Wheke, also known as the octopus, is another model used by Māori to represent the health of family/whānau, iwi or hapū. Introduced by Pere following a hui (tribal meeting) (Durie, 1995), the head of the octopus represents te whanau (family), the eyes of the octopus as waiora (overall wellbeing for the individual and family) and each of the eight tentacles represents a specific component of health (Love, 2004). These components are: wairuatanga (spirituality), hinengaro (the mind), taha tinana (physical wellbeing), whanaungatanga (extended family), mauri (life force in people and objects), mana ake (unique identity of individuals and family), ha a koro ma, a kui ma (breath of life from forbearers) and whatumanawa (the open and healthy expression of emotion) (Love, 2004). Each of these components is interwoven and is a representation of the close relationships 


\section{Te Wheke}

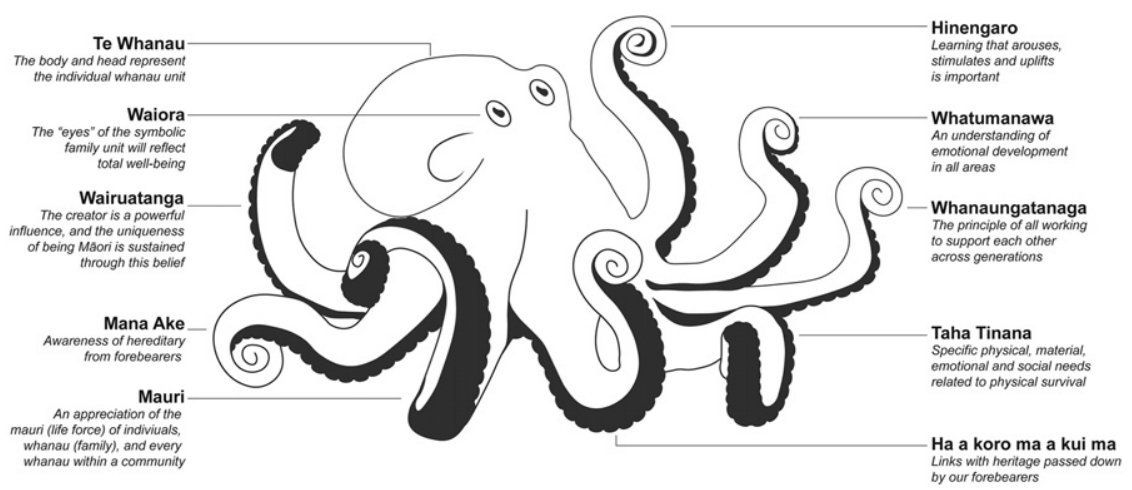

Fig. 11.3. Te Wheke or the Octopus, Brings Together Family with Wellbeing through a Comprehensive List of Elements That Are Intertwined. Source: Author's own

that exist between each health dimension. The model also illustrates that healthy individual selfhood is intertwined with and indivisible from the health of the family/whānau; and that the health of the family/whānau is inseparable from that of the hapū, and the health and wellbeing of the hapū is indivisible from that of the iwi. In this way, the model is applicable to both individuals and to groups (Pere, 2006) (Fig. 11.3).

The main finding from the models presented above is that balance between all elements of an individual's social, physical and spiritual life is critical for maintaining and supporting good health. If one element is neglected or receives too much attention then health suffers in all areas (Wilson, 2003). Each of the models provides a unique perspective; the Te Whare Tapa Wha model is simple and easily understood by all tribes and easily adaptable for a variety of communications. However, its simplicity is also the chief criticism of the model. It does not define the uniqueness of Māori as a cultural entity nor does it incorporate the sociocultural outcomes of the colonial experience (McNeill, 2009). Conversely, the Te Pae Māhutonga incorporates these outcomes 'through accessibility to a range of different Māori cultural experiences' (McNeill, 2009, p. 100) and highlights the importance of Māori leadership (Ngā Manukura) and autonomy (Te Mana Whakahaere). The limitations of this model are the potential for divisiveness and its failure to address the complexities of Māori spirituality. The Te Wheke model articulates the uniqueness of traditional Māori philosophical beliefs and values; however, it does not take into consideration Māori cultural deprivation. Furthermore, its complexity has proven difficult in practical application (McNeill, 2009). One aspect that is missing from these models is the connection with the land and how for Māori, the land supports all elements of life.

Responding to this imperative, the New Zealand government created Whānau ora (healthy families)- a complex concept that emerged from traditional Māori 
ways of viewing wellbeing. The creation of this organisation responded to the recognition that standard ways of delivering social and health services were not working and that outcomes for Māori health were not improving. Whānau ora introduces a delicate balance between the overall wellbeing of whānau (extended family members) and their connection to each other; their wider communities; their ancestors and the land; and, the physical, emotional, spiritual and social health of the individual with health and illness issues (Kara et al., 2011).

\section{How the Land Shapes Mäori Identity}

A significant aspect of health relates to the meaning of the land and its importance to Māori identity. Historically, Māori have always had a strong relationship with land (Papatūānuku, mother Earth) as it shapes the way in which they express their cultural, spiritual, emotional, physical and social wellbeing. By utilising what the land provides, individuals are able to attain the balance necessary to maintain a good level of health. In the Māori worldview, the land is seen as a powerful female entity who is a provider of all the physical and spiritual necessities required to sustain life (Panelli \& Tipa, 2007). Traditional Māori believe that people are born from the Earth and that this establishes the foundation for the relationship between the individual, whānau and nature.

Many Māori follow beliefs regarding their whakapapa (genealogical relationship) and interactions with plants, animals, people, the land and other aspects of the natural environment (Panelli \& Tipa, 2007). For instance, Ngāi Tahu (largest iwi located in the South Island of New Zealand) believes that the importance of whakapapa is demonstrated in their relationship with 'their territorial lands, their reverence for tüpuna (ancestors), their determination to exercise rangatiratanga (chiefly authority) and kaitiakitanga (the exercise of customary custodianship)' (Panelli \& Tipa, 2007, p. 450). Whakapapa is a significant source of identity for Māori as they believe that identity is not established by what a person does or by where they live, but that identity is linked by mauri (life force) to the mountains, waters and ancestral lands (Fig. 11.4). This reverence for natural environments and its influence in shaping Māori identity is captured in the phrase tangata whenua (literally people of the land).

Returning to the three approaches to Māori health and wellbeing described above, the relation between land and people illustrates how wellbeing is derived from the same place that also forms the ancestral roots of the culture. This suggests that the land is more than just a space in which people carry out daily activities. Instead forests, waterways and wetlands are therapeutic landscapes that Māori view as mediums for physical, emotional, mental and spiritual health and wellbeing. Māori view therapeutic landscapes through a 'whole of landscape' approach known as ' $k i$ uta ki tai' (to the mountains to the sea). This concept stresses the importance of recognising and managing the interconnectedness of the whole environment and the need to celebrate culture and identity. Taking the intertwined relationship of human and environment into account, the idea of a therapeutic landscape is thereby broadened to encompass issues of history, culture, memory and identity (Hepburn, Jackson, Vanderburg, Kainamu, \& Flack, 2010). 


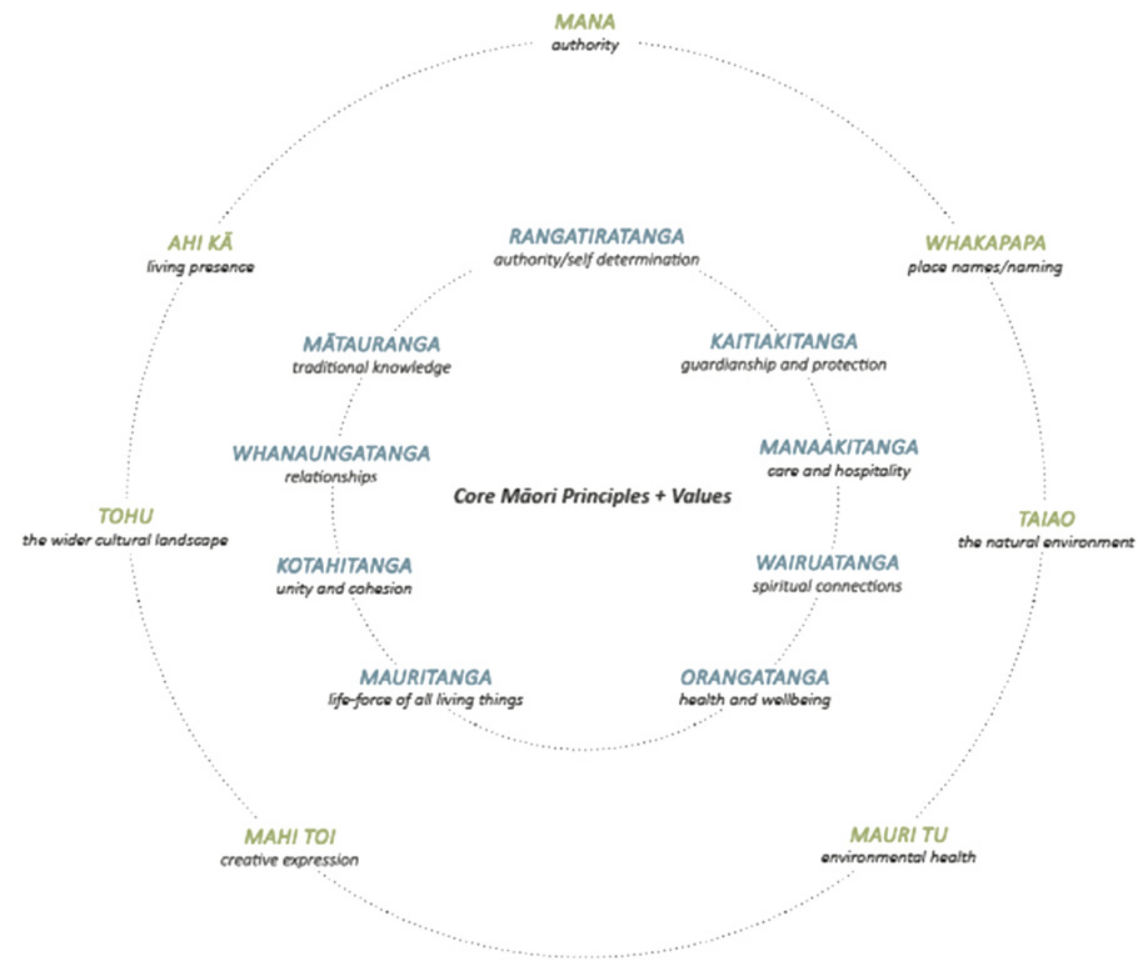

Fig. 11.4. Core Māori Principles and Values. Source: Hatton (2018), p. 106

\section{How Land Contributes to Health}

Māori separate the environment into four linked, yet unique areas. These are the whenua (the land), te wao nui a Tāne (the forest), nga wai ora (the water) and te rohe koreporepo (the wetlands). An understanding of the Māori view of these elements can aid in improving our understanding more specifically of how land contributes to health.

\section{Whenua: The Land}

The concept, whenua, has numerous meanings. These include land, country, ground, territory and placenta. According to the Māori view of the world, the natural environment has a deep meaning and must be nurtured. The traditional way of thinking states that the world is connected, and nature is the mother of all life. Ancestral connection to landscape is ultimately valued through interpretation, heritage, identity and status, providing people with a link to their past and to their future (Kawharu, 2009). In this way, the therapeutic attributes of landscape are centralised around life processes. If all things are related, and the landscape is not maintained correctly, then the health and wellbeing of all things become 
affected. The close engagement between people and environment is inseparable as there is no division between the material and non-material, the tangible and intangible (Kawharu, 2009). The combination of traditional knowledge and landscape engages people and nourishes their health and wellbeing while allowing them to develop and maintain therapeutic relationships with mana whenua (local people), whannau (family) and tangata whenua (people of the land). This also suggests that the identity of the people and the landscape are prerequisites for the good health of Māori people, linked by the ancestral knowledge of landscape through whakapapa (genealogy).

\section{Te Wao Nui a Tāne: Forests}

Forests enabled Māori to experience and make sense of the world. The therapeutic qualities allowed Māori to live as part of the natural environment through whakapapa, through containment of rare significant taonga (treasures) and through repositories of culture. Traditionally, forests were highly valued and were sought out places for spiritual domains, sources of food, places of education and places of healing (chemist/medicine). These fostered mana/power, responsibility, spiritual relationship, rangatiratanga/chieftainship, wellbeing and survival. When Europeans established themselves in Aotearoa/New Zealand, their practices meant the eradication of the rich forest ecosystems as agriculture, mono-culture tree farming and urbanisation gained pre-eminence. Approximately $60 \%$ of native forests were destroyed immediately following colonisation, and by 1840 , only $50 \%$ of the Indigenous forest survived. Today, only $23 \%$ of the original native forests remain (Ridley, Bain, Bulman, Dick, \& Kay, 2000). With introduced human activities and exotic species, those remaining Indigenous forests have been forced into steep, less productive and mountainous terrain unsuited for economic gain (Harmsworth, 1997). Overtime, the connection of people to the forest has waned, and the oral traditions have faded until only a small portion of forest knowledge remains (Marques, McIntosh, \& Kershaw, 2019a). In traditional understanding, forests were sources of mauri (life force), mana (power) and wairua (spirit). They were also sources of food through the customary harvesting of native birds, fish and plants, and sources of materials for construction of buildings and carving (whakairo). Ancestral beliefs maintained that the earthly and heavenly gods would provide and protect the natural environment. In these ways, therapeutic landscapes have always been considered by Māori as a means of lineage connecting all sources of life, reliant on the health and wellbeing of living things.

\section{Nga Wai Ora: Waterways}

Waterways provide an abundance of life with food and purification both contributing to the wellbeing of people. In oral traditions, water was seen by some groups as the source and foundation of life, rather than the land. For Māori, this is reflected through wairua which refers to the spiritual plane or may refer to the fundamental dimensions of all life in the form of water. The elements are air, earth, fire and water. Fire represents the underworld, air the heavenly skies or the afterlife, and water and earth the physical world. Water and earth form an 
inseparable bond vital to sustain and balance the natural environment. Traditionally, water has been classified in a number of ways: waikino, dangerous waters; waitapu, sacred waters; waimāori, pure water; waitai, seawater; waimanawa-whenua, water from beneath the land (springs); waikarakia, water for ritual purposes and waiwhakaika or waikotikoti, water to assist cutting of the hair (Williams, 2006). Māori lived and thrived near water as it sustained life. Some Māori, for example, those in geothermal areas around the central North Island, used the heated water; and hot-springs or geysers became places to bathe, cook and heal. The environment offered hapū (sub-tribes) and iwi (tribes) a close and distinctive knowledge of their surroundings.

Water meets therapeutic needs in providing cleansing, purification and sustaining life. Sadly, the growth of urban settlement has led to negative effects on natural waterways. Many Indigenous waterways are culverted, piped or redirected, destabilising natural water catchments and flows. The scarcity of water and the pollution of these systems are becoming more evident specifically with the depletion of lakes, springs, rivers, streams and oceans. For Māori, each body of water was considered to have its own life force. If water bodies contacted one another, both were at risk of having their ecosystem equilibrium disturbed (Durie, 1998). The mixing of water or the division of water bodies decreased the mauri (life force) in many places. These holistic views meant that for Māori, a water environment needing restoration or rehabilitation required its mauri or life force to be enhanced (Harmsworth, 1999). There is a discussion today on water treatment with the preference for impure water (mixed, polluted, land effluent or sewage) to be treated on land first rather than direct distribution into natural water ecosystems. By tackling these problems at the source, the betterment of people's wellbeing and health will enable both land and people to be sustained and the integrity of the mauri in each water body maintained (Durie, 1998).

\section{Te Rohe Koreporepo: Wetlands}

Wetlands derive from spiritual beings like all natural environments. The wetland systems play a key role in maintaining the integrity of the mauri (life force) of water bodies. They are highly valued by Māori and regarded as a taonga (treasure) as they were sources of food, traditional knowledge and materials. For over 800 years, human interaction with the wetlands created an active relationship with historical and cultural importance and values. In areas of urban intensification, wetlands were drained in the creation of the urban infrastructure. Many natural wetland systems lie beneath ever-growing cities, but their important role on the natural landscape is forgotten. Wetlands were a source of therapeutic health and wellbeing and enabled the collaboration of people and place. Wetlands are also often the interface between terrestrial ecosystems and freshwater ecosystems, therefore having a valuable role as part of the whole catchment, and enhancing stream and river health, and improving the mauri of waterways. By enhancing these water ecosystems, we can help to re-establish their traditional therapeutic values, creating a deeper connection to the landscapes so crucial to the environment. 


\section{Jacqueline McIntosh et al.}

Like many Indigenous cultures, Māori therapy seeks resources from the landscape in rongo $\bar{a}$ (herbal remedies), mirimiri (therapeutic massage) and honohono (spiritual massage, similar to reiki, traditional Japanese massage). These concepts are referred to as talking therapies, and they encompass the spiritual and psychological dimensions of health (Hopkirk \& Wilson, 2014). The core concepts of rongoa embrace spiritual healing and the use of traditional practices to support the four pillars of Māori health values. Mirimiri intends to link body, mind and soul with the environment, and rongo $\bar{a}$ is often involved as a way to connect to the elements. Like other holistic cultures, Māori believe in many spiritual alignments. Honohono represents the healing of a person's inner spiritual connection to themselves and the universe. It reflects on the change of a person's persona and environment, clearing and assisting in the transition of a person's mind, body and soul with their placement in the world (notion of place) (Marques, McIntosh, \& Hatton, 2018a; Te Pou, 2010).

The relationship between land and health is far more complex than what has been presented above, and there are many other issues that need to be considered but lie outside of the scope of this chapter. For example, men and women have different roles and therefore connect in different ways to the landscape (Wilson, 2003). Further research is needed to gain greater insights into the ways that gender shapes the relationship between health and place as well as the other issues relating to the material and symbolic aspects of place as positive agents for health.

\section{Discussion}

The rapid progression and development of social and cultural change today lacks an ideology around people and place. Reintroducing holistic models of health and wellbeing and revising current practices through a stronger (re) connection to the land is an achievable goal which can offer a framework for the future. In this chapter, we examined three Māori health models: Te Whare Tapa Whā, Te Wheke and Te Pae Māhutonga; which illustrate the challenges of finding a useful single model. These holistic constructs express the inner emotions of Indigenous culture but also offer potential for layering to provide the desired levels of specificity to suit unique tribal perspectives. They also all proffer ways which can inform the makeup of the therapeutic landscapes that underpin Māori identity.

Containment of identity is obtained through acknowledging the spiritual and tangible dimensions of life. But possessing strong cultural identity goes beyond knowing one's ancestral heritage; it takes into account the ecological, economic and social contexts that underpin the positive health of people. We maintain that holistic Māori views where 'using nature' and 'nurturing nature' are central to both wellness and therapeutic landscapes and should be seen as a part of modern ways of living. Too often, a dominant culture suppresses alternative ways of knowing and healing, and dominant forms of inhabitation similarly suppress other ways of living. 
Western cultures could learn much from the deep ideological connection between landscape and health and by adopting the principles and knowledge of Indigenous peoples. The application of the land connection with current health and wellbeing frameworks can thereby be regarded as essential in servicing Māori and Non-Māori health and wellbeing, having an adaptive integrity that is as valid for current generations as it was in the past. Incorporating Indigenous beliefs of stewardship and kinship with the land can also facilitate a restorative and therapeutic landscape and can offer new opportunities for living with nature in urban and rural contexts.

\section{Conclusion}

The aim of this chapter was to explore the role of therapeutic landscapes in shaping health, identity and wellbeing. The findings were presented in three stages by; firstly exploring Māori conceptions of health through a discussion of the three Māori health models; then by demonstrating the significance of the land as the basis of Māori identity; and finally, by examining the ways in which the land contributes to health. The research emphasises how the health of Māori might be improved by including conceptions of health and place that acknowledge the land as more than just physical or symbolic spaces for healing.

The framing of cultural responsiveness in therapeutic landscapes is usually written about in opposition to Western ideas in relation to the concepts of therapy, wellness and healing. One could speculate that this is due to the impact of colonisation and the spread of Western culture through globalisation. In colonised countries, most health treatments and the

...evidence-base for them have been developed within a Western colonial context, meaning that the implicit values, assumptions and methods often subjugate the epistemological frameworks and healing traditions of Indigenous people. (Smith, 1999, p. 487)

As such, the interpretation of a therapeutic landscape is only evident in sensory gardens, healing gardens and community food gardens.

This chapter maintains that trying to apply Western ideas of health and healing in an Indigenous context is inappropriate for a number of reasons including a fundamental misunderstanding of the role of landscape in Indigenous healing contexts. For Māori, the ideals inherent in these therapeutic landscapes are not separate entities, but part of a wider holistic system that caters for people's senses, emotions, values and enables links to the landscape. To move forward, research conducted within the framework of therapeutic landscapes must make room for the exploration of the links between health and place as manifested in the daily lives, cultures and geographies of all individuals. Through understanding Māori cultural and therapeutic landscapes, key concepts can be integrated into and produce meaningful and reflective environments. All three concepts; culture, health and landscape are interconnected and must be balanced to reduce Māori health inequalities and benefit the lands and all people of Aotearoa/New Zealand. 


\section{References}

Durie, M. (1995). Te hoe nuku roa framework a maori identity measure. The Journal of the Polynesian Society, 104(4), 461-470.

Durie, M. (1998). Whaiora: Maōri health development. Oxford: Oxford University Press.

Durie, M. (2004). An indigenous model of health promotion. Health Promotion Journal of Australia, 15(3), 181-185.

Durie, M. (2006). Measuring Māori wellbeing. New Zealand Treasury Guest Lecture Series, 1. Retrieved from https://www.treasury.govt.nz/sites/default/files/2007-09/ tgls-durie.pdf

Harmsworth, G. (1997). Maori values for land use planning. New Zealand Association of Resource Management (NZARM) Broadsheet, 97, 37-52.

Harmsworth, G. (1999). Coordinated monitoring of New Zealand wetlands: Building iwi partnerships. Landcare Research Contract Report LC, 9899085. Retrieved from https://citeseerx.ist.psu.edu/viewdoc/download?doi=10.1.1.485.6751\&rep= rep1\&type $=$ pdf

Hatton, W. (2018). Haumanu Ipukarea: Reviving tūrangawaewae, identity and place. Unpublished master's thesis. Victoria University of Wellington, Wellington.

Hepburn, C. D., Jackson, A., Vanderburg, P., Kainamu, A., \& Flack, B. (2010). Ki uta ki tai: From the mountains to the sea. Holistic approaches to customary fisheries management. Paper presented at the 4th International traditional knowledge conference. Retrieved from http://www.puketeraki.nz/site/puketeraki/ files/images/East $\% 20$ Otago $\% 20$ Taiapure $\% 20-\% 20$ Presentation.pdf

Hopkirk, J., \& Wilson, L. H. (2014). A call to wellness-Whitiwhitia i te ora: Exploring Māori and occupational therapy perspectives on health. Occupational Therapy International, 21(4), 156-165.

Houkamau, C. A. (2006). Identity and socio-historical context: Transformations and change among Māori women. ResearchSpace@ Auckland. Retrieved from http:// hdl.handle.net/2292/404

Kahn, R. L., \& Juster, F. T. (2002). Well-being: Concepts and measures. Journal of Social Issues, 58(4), 627-644.

Kara, E., Gibbons, V., Kidd, J., Blundell, R., Turner, K., \& Johnstone, W. (2011). Developing a Kaupapa Māori framework for Whānau Ora. AlterNative: An International Journal of Indigenous Peoples, 7(2), 100-110.

Kawharu, M. (2009). Ancestral landscapes and world heritage from a Māori viewpoint. The Journal of the Polynesian Society, 118(4), 317-338.

Kingsley, J., Townsend, M., Henderson-Wilson, C., \& Bolam, B. (2013). Developing an exploratory framework linking Australian aboriginal peoples' connection to country and concepts of wellbeing. International Journal of Environmental Research and Public Health, 10(2), 678-698.

Kokiri, T. P. (2000). Progress towards closing social and economic gaps between Mãori and non-Māori. Wellington: Te Puni Kokiri.

Lo, K. D., \& Houkamau, C. (2012). Exploring the cultural origins of differences in time orientation between European New Zealanders and Māori. NZJHRM, 12(3), $105-123$.

Love, C. (2004). Extensions on Te Wheke. Working Papers No. 6-04. The Open Polytechnic of New Zealand, Lower Hutt. 
Marques, B., Grabasch, G., \& McIntosh, J. (2018b). Fostering landscape identity through participatory design with indigenous cultures of Australia and Aotearoa/ New Zealand. Space and Culture. doi:10.1177/1206331218783939

Marques, B., McIntosh, J., \& Hatton, W. (2018a). Haumanu ipukarea, ki uta ki tai: (re)connecting to landscape and reviving the sense of belonging for health and wellbeing. Cities \& Health, 2(1), 82-90.

Marques, B., McIntosh, J., Hatton, W., \& Shanahan, D. (2019b). Bicultural landscapes and ecological restoration in the compact city: The case of Zealandia as a sustainable ecosanctuary. Journal of Landscape Architecture, 14(1), 44-53. doi: 10.1080/18626033.2019.1623545

Marques, B., McIntosh, J., \& Kershaw, C. (2019a). Healing spaces: Improving health and wellbeing for the elderly through therapeutic landscape design. International Journal of Arts and Humanities, 3(2), 20-34.

Marriott, L., \& Sim, D. (2015). Indicators of inequality for Māori and Pacific people. Journal of New Zealand Studies, (20), 24-50. Retrieved from https://search.informit. com.au/documentSummary; dn=276927349255099;res=IELHSS

McIntosh, J., Marques, B., \& Hatton, W. (2018). Indigenous cultural knowledge for therapeutic landscape design. In I. Rosa, J. Lopes, R. Ribeiro, \& A. Mendes (Eds.), Handbook of research on methods and tools for assessing cultural landscape adaptation (pp. 28-52). Hershey, PA: IGI Global.

McNaught, A. (2011). Defining wellbeing. In A. Knight \& A. McNaught (Eds.), Understanding wellbeing: An introduction for students and practitioners of health and social care (pp. 7-23). Banbury: Lantern Publishing.

McNeill, H. (2009). Māori models of mental wellness. Te Kaharoa, 2(1), 96-115.

Ministry of Health. (2015). Independent life expectancy in New Zealand 2013. Ministry of Health, Wellington.

Ministry of Health. (2019). Annual data explorer 2017/18: New Zealand health survey [data file]. Retrieved from https://minhealthnz.shinyapps.io/nz-health-survey-201718-annual-data-explorer

Panelli, R., \& Tipa, G. (2007). Placing wellbeing: A Māori case study of cultural and environmental specificity. EcoHealth, 4(4), 445-460.

Pere, R. (2006). Nga kawai rangatira o te wheke kamaatu: The eight noble tentacles of the great octopus of wisdom. Paper presented at the 10th Australasian Conference on Child Abuse and Neglect.

Ridley, G., Bain, J., Bulman, L., Dick, M., \& Kay, M. (2000). Threats to New Zealand's indigenous forests from exotic pathogens and pests. Science for Conservation, 142, 1-67.

Robson, B., \& Harris, R. (2007). Hauora: Māori standards of health 4. A study of the years 2000-2005. Wellington: Te Rpñ Rangahau Hauora a Eru Pmare.

Rochford, T. (2004). Whare Tapa Wha: A Māori model of a unified theory of health. Journal of Primary Prevention, 25(1), 41-57.

Selby, R. (1999). Still being punished. Wellington: Huia Publishers.

Smith, L. T. (1999). Decolonizing methodologies: Research and indigenous peoples. New York, NY: Zed Books.

Statistics New Zealand. (2013). Census-major ethnic groups in New Zealand. Retrieved from https://www.stats.govt.nz/infographics/major-ethnic-groups-innew-zealand. Accessed on January 30, 2016. 
Stewart, J. (2004). Mind-body health connections. In H. Keleher \& Berni Murphy (Eds.), Understanding health: A determinants approach (pp. 276-282). Oxford: Oxford University Press.

Te Pou. (2010). He Rongoa kei te Korero, talking therapies with Māori. Auckland: The National Centre of Mental Health Research; Information and Workforce development.

Thorns, D. C., Fairbairn-Dunlop, T. P., \& Du Plessis, R. (2010). Biculturalism, cultural diversity and globalisation: Issues for Aotearoa New Zealand. Korean Social Science Journal, 27(1), 93-122.

Waitangi Tribunal Report. (2019). Hauora: Report on stage one of the health services and outcomes kaupapa inquiry [Pre-Publication version]. Retrieved from https:// forms.justice.govt.nz/search/Documents/WT/wt_DOC_150429818/Hauora PrePubW.pdf

Walker, R. (1990). Ka whawhai tonu matou: Struggle without end (Vol. 220). Auckland: Penguin.

Wendt, D. C., \& Gone, J. P. (2012). Urban-indigenous therapeutic landscapes: A case study of an urban American Indian health organization. Health \& Place, 18(5), $1025-1033$.

Williams, J. (2006). Resource management and Māori attitudes to water in southern New Zealand. New Zealand Geographer, 62(1), 73-80.

Williams, A. (2009). Therapeutic landscapes as health promoting places. In T. Brown, S. McLafferty, \& G. Moon (Eds.), A companion to health and medical geography (pp. 207-223). West Sussex: Wiley-Blackwell.

Wilson, K. (2003). Therapeutic landscapes and first nations peoples: An exploration of culture, health and place. Health \& Place, 9(2), 83-93.

Wirihana, R., \& Smith, C. (2014). Historical trauma, healing and wellbeing in Māori communities. Mai Journal, 3(3), 197-210. 